\title{
Paying the price: nationalisation of private property or restoring the commons?
}

\author{
F. Rochford \\ La Trobe University, Australia
}

\begin{abstract}
In November 2009 Peter Spencer, an Australian Grazier, climbed a tower on his property in New South Wales and began a hunger strike. He claimed to be protesting against limits to vegetation clearing which effectively 'sterilised' his assets. He argued that land use constraints have been used as a carbon offset to ensure compliance with carbon reduction targets, but that they have rendered his land 'unviable'. Although he has discontinued his hunger strike, litigation in the High Court continues, claiming that limitations on land clearance are an expropriation of property attracting the provisions of the Australian Constitution which require compensation on 'just terms'.

This paper assesses tension between restrictions on private property and the interests of the community in addressing climate change, considering the justifications for private property. It considers the legal mechanisms by which restrictions have been imported, and the claim that the Australian Federal Government has avoided the requirement to pay compensation because the regulatory regime was introduced by the State of New South Wales, as a result of agreement with the Commonwealth. It then considers the potential for regulatory action to cast the burden of climate change on a few, without compensation, and considers issues of justice arising from realisation of that potential.
\end{abstract}

Keywords: sustainability, land use, property, law and policy.

\section{Introduction}

This paper examines the social and legal implications of legislation regulating land clearing on private land in Australia. Under the Kyoto Protocol, which Australia has now ratified, Australia is committed to containing its carbon 
emissions. However, carbon sequestered in forests or on agricultural land may be included in calculations of net greenhouse gas emissions. Whilst Australia has significant public land $-23 \%$, or 1767.9 thousand square kilometres of Australian land is public (Geoscience Australia [1]) - private land is included in attempts to comply with Australia's commitments under multiple environmental policies. Federal and state enactments, developed through co-operative mechanisms, have delivered significant impetus to Australia's attempts to comply with limitations on carbon gas emissions by 'locking up' private land, thus preventing deforestation. However, this has resulted in significant rural disquiet, both as a consequence of constraints on rural land use which have forced changes to rural business enterprises, and because of the perception that individuals are unfairly bearing the cost of Australia's quest for compliance with emissions targets, while the federal government has avoided the constitutional obligation to pay compensation by technical legislative devices.

Peter Spencer, a grazier with a 12000 acre property near Cooma, New South Wales, became the lightning rod for rural discontent in a 52-day hunger strike, galvanising popular (Rehn [2]) and political support (Arup and Reilly [3]). He commenced litigation, firstly - and unsuccessfully - in the Federal Court, then on Appeal in the Full Court of the Federal Court. The High Court on appeal, however, allowed his appeal.

This issue has significant implications for Australian attempts to comply with emissions targets within budgetary limits, but also raises issues of justice. Compensation for government appropriation of private property is mandated in Australia's Federal Constitution, but is not constitutionally demanded of state governments. Where incorporeal benefits, such as carbon sequestration rights, are severed from the title to real property and effectively appropriated by state action, this can have impacts on other property interests. Conversely, limitations on land use for carbon sequestration (and biodiversity), impose significant land use and planning restrictions on a large amount of Australian rural land. This recognises that whilst around 13 per cent of native vegetation has been cleared since 1750, the remaining 87 per cent consists of variable and fragmented cover. Restrictions on clearing apply to both established native vegetation and regrowth, so impact on land use and planning decisions in a massive swathe of private land.

\section{Australia's carbon emission framework}

The United Nations Framework Convention on Climate Change (UNFCCC [4]) and Australia's subsequent accession to the Kyoto Protocol under the Convention in 2007 committed it to greenhouse gas emissions targets based on 1990 greenhouse gas emission levels (UNFCCC [5]). Australia is committed to contain its greenhouse gas emissions to $108 \%$ of the 1990 baseline.

One of the ways in which Australia intended to meet this target was by the development of an emissions trading scheme, the Carbon Pollution Reduction Scheme, a cap-and-trade style policy which would have imposed annual quantity caps on overall emissions. Those emitters not excluded from the scheme would 
have had to acquire permits equivalent to their emissions, or to pay an emissions fee (Hepburn [6] p.243). The scheme was intended to be introduced by 2011, but was rejected in the Australian Parliament in August (the Carbon Pollution Reduction Scheme Bill 2009) and again in December 2009 (the Carbon Pollution Reduction Scheme Bill 2009 (No 2)). An amended version was reintroduced in February 2010 (the Carbon Pollution Reduction Scheme Bill 2010) and passed through the chamber, but lapsed in the Senate in September 2010 when a general election was called. (Department of Climate Change and Energy Efficiency [7]; Parliament of Australia, Parliamentary Library [8])

An emissions trading scheme remains one mechanism to ensure Australia's compliance with its obligations under the Kyoto Protocol, but the current Australian Labor federal government has not attempted to reintroduce it in this form. Instead, the development of a 'carbon tax' has recently been announced, effectively to 'price' carbon emissions (Shanahan [9]) - although a significant voter backlash at this apparent breach of a pre-election promise signifies that this may also face political difficulties (see e.g. Franklin [10]; Kelly [11])

Whilst agriculture is currently excluded from the proposed taxation of greenhouse emissions (Kelly [12]), agricultural and forested land is particularly useful to reducing emissions under the Kyoto protocol because it has been accepted as a source of carbon offsets.

The sequestration process refers to the natural absorption from the atmosphere of carbon dioxide by vegetation and soils and the storage of carbon in vegetation and soils. In this respect, the primary focus of the carbon sequestration right is upon storage rather than removal and the interest confers rights upon the holder to the benefits that may flow from such storage and storage potential (Hepburn [6] p.243).

The reconceptualisation of the real property right in order to identify, register and trade in carbon sequestration rights, however, is challenging. Hepburn notes that '[p]roperty systems are inherently conservative, seeking continuity in their basic internal framework' (Hepburn [6] p.240). However, the 'newer agents of economic development' (Hepburn [6] p.240) demand more, stimulating an evolution in the law of property. She notes that

$[\mathrm{t}$ ]he shift from a static agrarian conception of property, whereby an owner was essentially entitled to undisturbed enjoyment, to a more dynamic, instrumental, and abstract view of property in the 19th century, emphasising newly paramount virtues of productive use and land development, encouraged greater awareness of the utility of title fragmentation. (Hepburn [6] p.240)

Australian jurisdictions have a history of innovation in market-based solutions to natural resource issues, and the capping of water extractions and severance of water from land has already enabled the creation of a partial 'grid' for water transferrals to ameliorate drought and to allow water to be transferred to the most efficient use. Victoria's 'BushBroker' scheme similarly enables the offsetting of authorised vegetation clearances by the establishment of sites that can generate Native Vegetation Credits (DSE [13]). The cap-and-trade mechanism to facilitate the reduction in carbon emissions follows similar 
economic reasoning. However, whereas in most states water has historically been reposed in the state, and generally required licensing and payment for water use, the development of a market superstructure for carbon emissions requires an alteration in generally accepted real property title concepts. This has been effected by new or amended legislation in most state jurisdictions. Most states in Australia have legislation severing the carbon sequestration capacity of land from the land itself, thus enabling trade in carbon offsets (Conveyancing Act 1919 (NSW) ss 87A, 88AB(1), 88EA; Forestry Act 1959 (Qld) s 61J(5); Forestry Rights Registration Act 1990 (Tas) s 5; Forest Property Act 2000 (SA) s 7; Carbon Rights Act 2003 (WA) s 6; Carbon Rights Act 2003 (WA) s 6; Forests Rights Act 1996 (Vic) ss 3, 4). The methods of validating the carbon interest differ; in some states it is in the form of a profit à prendre, in some a new statutory interest, and in some an interest contingent on registration of a carbon agreement (Hepburn [6] p.246). However,

[t] he primary feature of the carbon rights legislation in each State in Australia is the validation of the carbon right as a land interest separate from the land upon which it is situated. In this respect, the legislative provisions have amended the established common law presumption that trees growing upon the land and the carbon contained within those trees are a natural part of the land and therefore belong to the landowner. (Hepburn [6] p.247)

Generally speaking, legislation in this form has concentrated on the establishment or maintenance of forests for carbon sequestration, and presuppose either the establishment of treed areas or the continuation of forests deliberately set aside for that purpose. The legislation enables creation and dealing with an interest in the carbon abatement properties of the treed land. This 'relatively narrow focus' (Kennett et al. [14] p.208) means that many of the innovations of Australian farmers through no-till farming and nutrient management will not be considered to be carbon sequestration.

Legislation in other forms, however, mandates the preservation of native vegetation or regrowth on Australian private land. Because of restrictions on land clearing, the owner of the real property may no longer have a full range of choice as to the use of that land. As will be seen, there are significant restrictions on the clearing of native vegetation by private landowners, and this is of significant benefit to Australia's efforts to comply with the Kyoto Protocol. Since the primary purpose of the native vegetation protection legislation is the protection of biodiversity, the trade-off between agricultural and afforestation as carbon sequestration techniques is, perhaps, understandable, but the focus on forest sequestration to the exclusion of the potential for other agricultural activities for carbon sequestration is problematic.

\section{Prohibitions on land clearing}

Land clearing is regulated federally by the Environment Protection and Biodiversity Conservation Act 1999 (Cth). Each state has its own legislation and framework for the maintenance of native vegetation. In New South Wales the 
Native Vegetation Act 2003 (NSW) (previously the Native Vegetation Conservation Act 1997 (NSW) sets out landholder responsibility for native vegetation on private land. In Queensland, clearing of native vegetation is governed by the Vegetation Management Act 1999 (Qld) and the Sustainable Planning Act 2009 (Qld). In addition the State Policy for Vegetation Management and regional vegetation management codes provide policy and assessment tools against which the Acts are to be administered. Victorian landowner obligations are contained in the Flora and Fauna Guarantee Act 1988, (Vic), the Planning and Environment Act 1987 (Vic) and the Catchment and Land Protection Act 1994 (Vic) supplemented by the Native Vegetation Management: A Framework for action (2002), which espouses a 'net gain' principle, under which native vegetation removal is subject to permit and must be 'offset' by setting aside suitable land or by planting native vegetation. It has been incorporated into Victorian Planning Provisions since July 2003. The Environmental Protection Act 1986 (WA) and the Environmental Protection (Clearing of Native Vegetation) Regulations 2004 place similar controls over clearing of native vegetation in Western Australia. In South Australia, the Native Vegetation Act 1991 (SA), in the Northern Territory Planning Act or the Pastoral Land Act 1999, whereas the vegetation harvested for commercial purposes is covered by Territory Parks and Wildlife Conservation Act. In Tasmania Forest Practices Act 1985 (Tas) regulates clearing of threatened species. In the Australian Capital Territory clearing of native vegetation is controlled by the Land (Planning and Environment) Act 1991 and the Nature Conservation Act 1980.

Prohibitions on clearance of native vegetation can have significant impacts on the capacity of rural landowners to fully utilise their land in an economic sense. Sinden [15] demonstrates that there is public benefit in protection on native vegetation on private land, but that private landholders incur significant cost by those measures (Sinden [15]). However, the extent of the value to the public, and the loss to the individual, varies considerably, particularly according to the type of soil, the extent of clearing, and the accessibility of the land. Not all of the value to the public is contained in the carbon sequestration capacity of the land; biodiversity protection, catchment benefits, decreased land degradation downriver, and presumably amenity benefits would accrue. Benefits would potentially equal the costs, but the distribution of costs remains an issue (Sindon [15] p.221). Whilst acknowledging that the manner and extent of conservation protection 'is, of course, primarily an environmental question and not an economic one' (Sindon [15] p.221), Sindon notes that

[t]he evidence from north-western New South Wales indicates that there can be gains in land value, losses in land value, or no change at all, when landholders are required to protect native vegetation on their farms. But the losses, or potential increases that cannot now be realised, are common, widespread and often large. They will be very large when the alternative agriculture is very productive and large percentages of vegetation remain on the farm (Sindon [15] p.222). 
Conversely, the capacity of landowners to participate in a carbon credits market is currently limited by the lack of a legal and regulatory framework for determining the initial ownership of carbon sequestered on private land and for the trade in those interests (Kennett et al. [14]). The capacity to mitigate losses through these mechanisms is, therefore, limited. There are emissions trading schemes currently operating outside Kyoto, and there are examples of Australian businesses using cap-and-trade style mechanisms (Thompson and CampbellWatt [16]).

\section{The case}

In Spencer v Commonwealth of Australia [2010] HCA 28 (1 September 2010) the applicant, Spencer, held freehold and leasehold interests in a farm in New South Wales. As a consequence of restrictions on the clearing of native vegetation imposed by the Native Vegetation Act 2003 (NSW) and its predecessor legislation, Spencer claimed that he was unable to farm. In effect, he argued that his land had been economically neutralised. He had evidence to support this claim: the New South Wales Rural Assistance Authority assessed the property as commercially unviable because of his inability to clear native vegetation. At first instance in the Federal Court Emmet $\mathbf{J}$ held that Spencer had no real prospect of obtaining the relief he source, and granted the Commonwealth's application that the proceedings be summarily dismissed. On appeal to the Full Court of the Federal Court (Black CJ, Jacobson and Jagot JJ) [17] Spencer's appeal against summary dismissal of his claim was also dismissed.

In the proceedings Spencer claimed that his property had effectively been expropriated. However, he argued that this constituted a constitutional 'acquisition' under s.51(xxxi) of the federal constitution - that is, that the acquisition was by the federal government. In the lower courts his case was summarily dismissed. Applying Pye v Renshaw [1951] HCA 8; (1951) 84 CLR 58 and following Arnold $v$ Minister Administering the Water Management Act 2000 [2008] NSWCA 338 the courts below held that the acquisition had not been effected by the federal government, but by the operation of the New South Wales Act. The arrangement between the state and federal governments did not change that position. In dismissing the appeal from the primary judge, the Full Court of the Federal Court concluded that

In common with the primary judge it is easy to sympathise with Mr Spencer if the effect of the State statutes has been to sterilise his land from any productive activity. Nevertheless that does not alter the fact that the proceeding has no reasonable prospect of success and the primary judge was correct to so conclude Spencer v Commonwealth of Australia [17] [para 36]).

In Spencer v Commonwealth of Australia [2010] HCA 28 (1 September 2010) the High Court, however, granted special leave to appeal and the appeal was allowed. The High Court held that Spencer's case 'potentially involves important questions of constitutional law', and raised issues of fact which could justify pre-trial processes denied by summary judgement. Further, the High 
Court's decision in ICM Agriculture Pty Ltd v The Commonwealth (2009) 240 CLR 140; [2009] HCA 51, which was heard by the High Court before the Full Court of the Federal Court had delivered their judgments, had an impact on whether pre-trial proceedings would be appropriate to ascertain the factual position in relation to the intergovernmental arrangements at the centre of Spencer's claim (French CJ and Gummow J [para 4]).

\section{Expropriation of property and 'just terms'}

Spencer, along with predecessor cases in ICM Agriculture Pty Ltd $v$ The Commonwealth (2009) 240 CLR 140; [2009] HCA 51 and Arnold v Minister Administering the Water Management Act 2000 [2010] HCA 3 (10 February 2010), suggest increasing tension in techniques of co-operative federalism that have delivered a significant proportion of Australia's planning and environmental legislation. The desire to plan and manage natural resources on an ecosystem level strikes significant constitutional impediments when the legislative power over private land and water is generally reposed in the states. Over the past few decades, federal and state governments have circumvented the federal government's constitutional limitations by an increasing array of interlocking or co-operative legislation. Land clearing restrictions typify the approach. Spencer's argument was that the Native Vegetation Act 2003 (NSW) and its predecessor legislation contained prohibitions and restrictions on land clearing that effected an acquisition of his interests in his property. Critically, however, he argued that the acquisition was made in furtherance of agreements between New South Wales and the Commonwealth. The agreements cited were the Agreement between the Commonwealth of Australia and the State of New South Wales, 31 October 1997, which provided the basis for funding by the Commonwealth of programs addressing clearance of native vegetation, the Intergovernmental Agreement on a National Action Plan for Salinity and Water Quality, 3 November 2000, which provided funding for measures addressing salinity, the Agreement between Commonwealth of Australia and State of New South Wales Relating to the National Action Plan for Salinity and Water Quality, 17 May 2002, which, inter alia, allocated funding and addressed potential federal contribution to compensation requirements, and the Bilateral Agreement between the Commonwealth of Australia and the State of New South Wales to Deliver the Extension of the Natural Heritage Trust, 14 August 2003, which referred to an intention to work as 'joint investment partners' with other stakeholders in natural resource management. Spencer argued that those agreements, and the laws which authorised them - the Natural Resources Management (Financial Assistance) Act 1992 (Cth) and the Natural Heritage Trust of Australia Act 1997 (Cth), were made for the purpose of acquiring property other than on just terms and were invalid by reason of s 51(xxxi) of the Constitution.

Section 51(xxxi) of the Constitution provides that the federal Parliament has power to make laws with respect to 'the acquisition of property on just terms from any State or person for any purpose in respect of which the Parliament has power to make laws'. Spencer claimed that his property was being acquired on 
other than just terms. In particular, he claimed that the carbon sequestration rights over his property were acquired by the commonwealth for the purpose of forwarding Australia's compliance with the Kyoto protocol, and that if the federal government had been obliged to acquire those rights directly it would have had to pay just compensation.

The critical issue for Spencer was the characterisation of the relationship between the state and federal acts - whether an 'informal arrangement between the Commonwealth and the State of New South Wales conditioning the relevant Commonwealth funding upon acquisition by the State of Mr Spencer's property rights on other than just terms' (French CJ and Gummow J [para 31]). Practically, then, the High Court has facilitated an enquiry into the relationship between the very common funding arrangements between the Commonwealth and the states which enable the federal government to pursue environmental goals using state legislation.

\section{Political and social implications}

The technical arguments presented in Spencer, as in ICM and Arnold before it, belie the serious issues of justice presented in these cases. The right to just compensation for expropriation of private property is arguably one of the foundational constitutional principles in English law. The Constitutional right to compensation is 'designed to bar Government from forcing some people alone to bear public burdens which, in all fairness and justice, should be borne by the public as a whole' (Armstrong $v$ United States [18]). Constitutional protection against uncompensated expropriation of property has been traced back to the Magna Carta, Blackstone and Locke (Christie [19]). A failure to provide compensation allows the individual to bear the costs of social objectives alone, where justice would prescribe that it be distributed across the wider community. Certainly, from the perspective of the Australian rural community, there is a perception that the failure to provide sufficient compensation for constraining land use decisions is unfair, and when the benefits to the wider community outweigh those to the landowner affected that perception is crystallised. Landowners whose land has been economically neutralised in pursuit of national objectives but who have been offered insufficient or no compensation would be justified in thinking that their property has been effectively nationalised.

However, Australia's capacity to forward significant sustainability objectives is constrained by its Constitutional framework - 'the Australian Constitution prescribes and limits the Commonwealth's power to legitimately allow a national emissions trading system within Australia' (Garner [20]), just as it limits its capacity to forward a national program for regulation of water extraction and use, and a national agenda for biodiversity conservation.

The High Court's decision in Spencer does not provide a final answer on the Constitutional propriety of the funding arrangements that have purchased state support for environmental programs. However, it could signal a serious disruption to the accepted realpolitick of fiscal federalism in Australia, and may 
prompt a rebalancing of federal/state relations. It is not clear, however, that the current restrictions on private property activity will be dismantled.

\section{References}

[1] Geoscience Australia (nd), Land Tenure http://www.ga.gov.au/education/ geoscience-basics/land-tenure.html.

[2] Rehn, A, 'Mass rally for pole sitting hunger striker Peter Spencer' Herald Sun January 4, 2010, http://www. heraldsun.com.au/news/national/mass-rally-for-pole-sitting-hunger-strikerpeter-spencer/story-e6frf716-1225815790482.

[3] Arup, T, and Reilly, T, 'Fears of lasting harm to body ended hunger strike' Brisbane Times January 14, 2010 http://www.brisbanetimes.com.au/ national/fears-of-lasting-harm-to-body-ended-hunger-strike-20100113m71k.html.

[4] UNFCCC (United Nations Framework Convention on Climate Change), opened for signature 9 May 1992, 1771 UNTS 107 (entered into force 21 March 1994) http://unfccc.int/2860.php.

[5] UNFCCC, 'Status of ratification' http://unfccc.int/kyoto protocol/ status of ratification/items/2613.php.

[6] Hepburn, S, 'Carbon rights as new property: the benefits of statutory verification' (2009) 31 Sydney Law Review 239 - 271.

[7] Department of Climate Change and Energy Efficiency (nd)) http://www.climatechange.gov.au/government/initiatives/cprs.aspx.

[8] Parliament of Australia, Parliamentary Library (nd) http://www.aph.gov. au/library/pubs/climatechange/governance/domestic/national/cprs.htm.

[9] Shanahan, D, 'Carbon price 'would need to be tripled' to force change from coal-fired electricity' The Australian March 12 , 2011 http:// www.theaustralian.com.au/national-affairs/carbon-price-would-need-to-betripled-to-force-change-from-coal-fired-electricity/story-fn59niix1226020025233.

[10] Franklin, M, 'Julia Gillard puts carbon tax on US agenda' The Australian March $11^{\text {th }} 2011$ http://www.theaustralian.com.au/news/julia-gillard-putscarbon-tax-on-us-agenda/story-e6frg6n6-1226019468733.

[11] Kelly, P, 'Gillard has no choice but to fight' The Australian March $12^{\text {th }}$, 2011 http:/www.theaustralian.com.au/national-affairs/commentary/gillardhas-no-choice-but-to-fight/story-e6frgd0x-1226019974555.

[12] Kelly, J, 'Climate change adviser recommends agriculture be included in a carbon price regime' The Australian March $1^{\text {st }}, 2011$ http:/www.theaustralian.com.au/national-affairs/climate-change-adviserrecommends-agriculture-be-included-under-a-carbon-price-regime/storyfn59niix-1226014181851).

[13] DSE (Department of Sustainability and Environment) (nd) http:/www.dse.vic.gov.au/DSE/nrence.nsf/LinkView/90D1EEF7733B9CD 7CA256FA4001617CE4F65BBF1E5A3A721CA25720C00167A65. 
[14] Kennett, S, Kwasniak, A, and Lucas, A, 'Property rights and the legal framework for carbon sequestration on agricultural land' (2005-6) 37 Ottawa Law Review 171 - 213.

[15] Sinden, J A, 'Do the public gains from vegetation protection in NorthWestern New South Wales exceed the landholders' loss of land value?' (2004) 26(2) Rangeland Journal 204-224.

[16] Thompson A, and Campbell-Watt, R, 'Australia and an emissions trading market - opportunities, costs and legal frameworks' (2005) 24 Australian Resources and Energy Law Journal $151-171$.

[17] Spencer v Commonwealth of Australia [2009] FCAFC 38 (24 March 2009).

[18] Armstrong v United States, 364 U.S. 40, 49, 4 L. Ed. 2d. 1554, 1561 (1960).

[19] Christie, D R, 'A Tale of Three Takings: Taking Analysis in Land Use Regulation in the United States, Australia and Canada' (September 2006). FSU College of Law, Public Law Research Paper No. 186; Brooklyn Journal of International Law, Vol. 32, No. 2, 2007. Available at SSRN: http://ssrn.com/abstract=882096.

[20] Garner, R, 'Regulating a national emissions trading system within Australia: Constitutional limitations' (2006) 3 Journal of International and Comparative Environmental Law 83 - 112. 